International Journal of Engineering \& Technology, $7(2.2)(2018) 45-47$
International Journal of Engineering \& Technology
WPC
Website: $w$ ww.sciencepubco.com/index.php/IJET
Research Paper

\title{
Registration System and UTM Games Decision Using the Website Application
}

\author{
Fatin Azura Ahmad Fauzy ${ }^{1 *}$, Zuraini Ali Shah ${ }^{1 *}$, Rd Rohmat Saedudin², Shahreen Kasim \\ Ayu Alyani Azadin ${ }^{4}$, Ansari Saleh Ahmar ${ }^{5}$, Rahmat Hidayat ${ }^{6}$ \\ ${ }^{1}$ Faculty of Computing, Universiti Teknologi Malaysia, Skudai, Johor, Malaysia \\ ${ }^{2}$ School of Industrial Engineering, Telkom University, Bandung, West Java, Indonesia \\ ${ }^{3}$ Faculty of Computer Science and Information Technology, Universiti Tun Hussein Onn Malaysia, Johor, Malaysia \\ ${ }^{4}$ Findbulous Technology Sdn Bhd, Cyberjaya, Selangor, Malaysia \\ ${ }^{5}$ Department of Statistics, Universitas Negeri Makassar, Makassar, Indonesia \\ ${ }^{6}$ Department of Information Technology, Politeknik Negeri Padang, Indonesia \\ *Corresponding author E-mail: aszuraini@utm.my
}

\begin{abstract}
UTM Games is an annual sports tournament organized by UTM Sports Excellence involving students, staff team, PELUAS (International Student Team) and International Campus Kuala Lumpur. There are 14 types of contested games such as volleyball, soccer, squash, netball, bowling, badminton, kayaking, futsal, sepak takraw, table tennis, tennis, basketball, cycling, and lawn bowls. Currently registration and review of result for UTM Games are still done manually and on papers for some of the residential colleges. While for some other residential colleges, registration and review of results are done by web applications such as in Tun Ghafar Baba College (KTGB). Therefore, the Registration and Review of Results for UTM Games using Smart Phone is developed because most users nowadays have a smartphone and internet access. In addition, the system allows the user to see the results of UTM Games without having to log into social sites such as Facebook. The system is developed using ASP.Net technology and Microsoft Visual Studio 2010. The methodology used in developing this system is a prototype evolving methodology. This methodology allows the user to provide feedback and insights to add dynamically. The prototype will be modified according to the views and feedback given. The system is a platform to make it easier for managers to register for the game. In addition, the system is developed to enable students to review results from UTM Games more quickly and accurately.
\end{abstract}

Keywords: Registration System, UTM Games.

\section{Introduction}

Every year Universiti Teknologi Malaysia (UTM) will organize UTM Games. UTM Games is a sports tournament involving all residential colleges, staff teams, PELUAS (International Student Team) and Kuala Lumpur International Campus. The UTM Games Championship is organized by UTM Sports Center. Registration for game managers and players will be managed by UTM Games committee members for each college and usually the results of the game will be uploaded on social sites like Facebook or on the residential college's website [1].

Currently registration and review of UTM Games results are still done offline and on papers for some residential colleges. Meanwhile, for some other residential colleges, the registration system and UTM Games decision review are done via web applications such as in Tun Ghafar Baba College (KTGB). This system is generally uncoordinated by the organizers of the games.

There are many things to consider in developing this system, including the information management of game managers and players who manually register, as well as registration records and UTM Games sports championship results. Looking at these per- spectives, there are still many weaknesses that need to be fixed in this system.

Problems arise on the registry when the manually written form is lost or the information posted is incorrect. This will result in loss of registration records and can cause confusion on the implementing committee to update registration information. In addition, there is a problem for students who want to know the results of UTM Games. Students need access to social sites such as Facebook or college website because UTM Games results review system is not aligned [2].

These problems can be solved by the presence of a smartphonebased system. This is because most students today use smartphones as a medium for obtaining information. With this smartphone application, students can register and acquire UTM Games results faster and more accurately. The UTM Games results registration and review system needs to be developed with a smartphone-based application to facilitate students and improve the existing system vulnerabilities [3].

Comparison is made to investigate the features of several existing system that serves the same function as the proposed system. The Sports Agency's Registration System (ROSAc) is a system that allows users to submit application for sports body registration, application of operating license, renewal of licensing, tournament 
licensing application, information (MYKB PT1), information provided (MYKB PT2), amendments of constitution, dissolution, cancellation, information search and system administration. This application allows the process of submitting documents only via uploading documents and there will be email notifications sent for every work process carried out by users and officers on duty [4].

The KTGB UTMGames Application System is developed by Tun Ghafar Baba College (KTGB), UTM. This system caters for students who wish to register as game managers and players to represent the college. This registration form is developed using Google Document. Players need to register by filling out the form provided (Google document). This registration form can be accessed through the website address posted on KTGB's residential college website [5]

This system was developed by Ipoh Teacher Education Institution (IPG). The system was developed to assist student affairs (HEP), discipline, graphics, dormitories, and IPG management to effectively handle student information. The system has garnered several quality awards in 2008 due to the efficiency and effectiveness of the initiative.

\section{System Implementation}

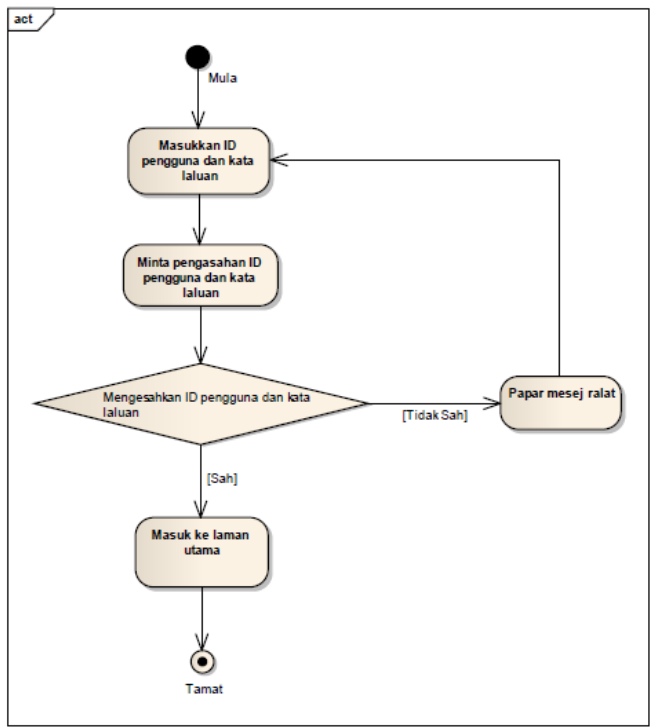

Fig. 1: Registration System and UTM Games Result Using The Website Application

The information system is develop using web programming and make decision support system [6]-[9]. Figure 1 shows an activity diagram for a login use that describes each activity performed by the user. User will input the registered user ID and password. The system will verify the user ID and password. If the user ID and password are invalid, the system will display an error message requiring the user to enter the user ID and password again.

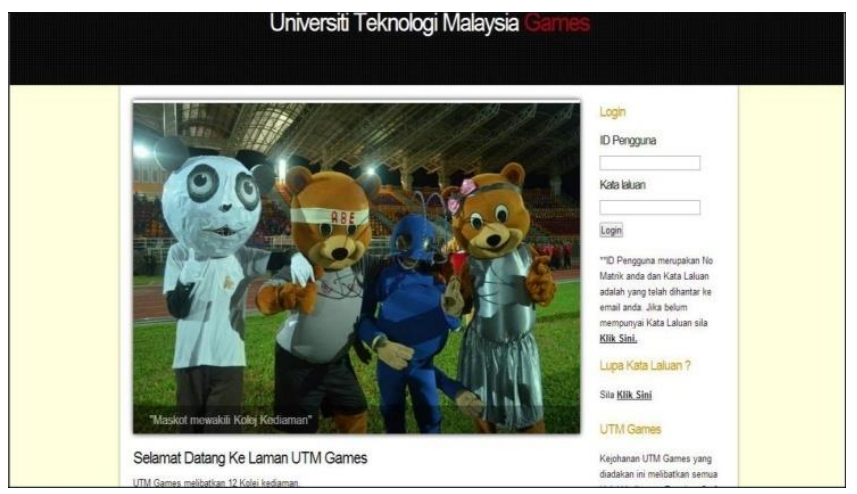

Fig. 2: System Main Interface

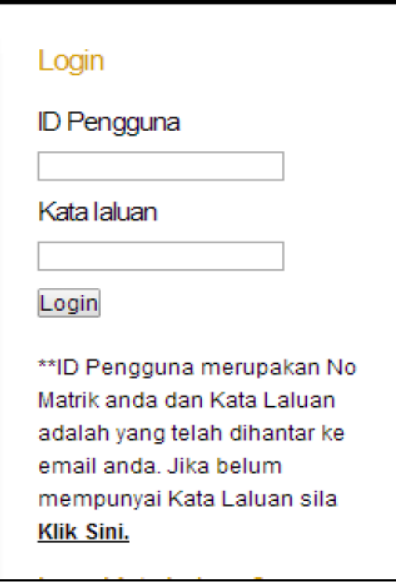

Fig. 3: Login Interface

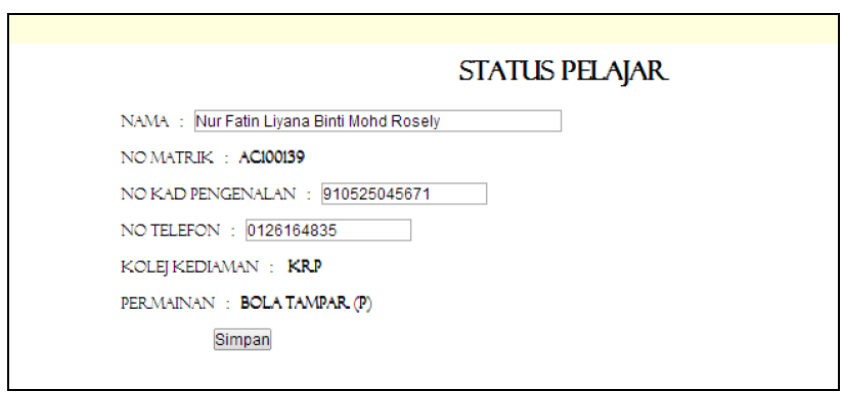

Fig. 4: Views for Students Registered as Players

STATUS PELAJAR
MAAF,ANDA TIDAK TERLIBAT DENGAN UTM GAMES
NAMA :
NOMATRIK:
NO KAD PENGENALAN :
NO TELEFON :
KOLEJKEDLAMAN :
PERMAINAN :

Fig. 5: Views for Students Not Registered as Players

\begin{tabular}{|c|} 
KEPUTUSAN UTM GAMES \\
PERMAINAN : Bola Tampar (L) Hantar \\
Bola Tampar (L) \\
Johan : Kolej Tunku Canselor \\
Naib Johan : Kolej 10 \\
Ketiga : Kolej Perdana
\end{tabular}

Fig. 4: View UTM Games Result

\section{System Testing}

The functionality of UTM Games Result Enforcement and Registration System will be tested to make sure that the developed system meets the requirements stated by the client. The testing is carried out on different aspects of the system, including administrative panel functionality. The types of testing are functional testing and non-functional testing. Functional testing ensures that the function of developed system meets client's requirement while non-functional testing is used to test the performance of the system. The non -functional testing techniques used are load testing, compatibility testing, security testing, and usability testing. Load 
testing is to test the system response under normal and stress load condition. Usability testing is to show that user can produce high productivity by using the developed system. The purpose of this test is to determine whether the system interface and function is apparent enough for user to understand. On the other hand, security testing ensures data integrity and safety. All testing results are recorded in a table. There will be three parts of processes in the testing phase, which are test case, expected result and actual result. The word "success" and "fail" indicate whether the tested field can function properly or not.

\section{Login Case Test}

Table 1: Result of Testing on a Module Login

\begin{tabular}{|c|c|c|c|}
\hline Input & $\begin{array}{c}\text { Path } \\
\text { Tested }\end{array}$ & Expected Result & Actual Result \\
\hline $\begin{array}{l}\text { Input for user ID } \\
\text { and valid pass- } \\
\text { word }\end{array}$ & $a-b-c$ & Login successful & $\begin{array}{l}\text { Login successful. The } \\
\text { main menu displayed }\end{array}$ \\
\hline $\begin{array}{l}\text { Input for user ID } \\
\text { only }\end{array}$ & a-d-e & $\begin{array}{l}\text { Sign in unsuc- } \\
\text { cessful and error } \\
\text { message is dis- } \\
\text { played. }\end{array}$ & $\begin{array}{l}\text { Login unsuccessful } \\
\text { and error message } \\
\text { tells the user to enter a } \\
\text { correct user ID and } \\
\text { password displayed } \\
\text { Sign in not successful }\end{array}$ \\
\hline $\begin{array}{l}\text { Sign in unsuc- } \\
\text { cessful and error } \\
\text { message is dis- } \\
\text { played. }\end{array}$ & a-d-e & $\begin{array}{l}\text { Sign in unsuc- } \\
\text { cessful and error } \\
\text { message is dis- } \\
\text { played. }\end{array}$ & $\begin{array}{l}\text { and error message } \\
\text { user } \\
\text { to enter an ID users } \\
\text { and correct passwords } \\
\text { displayed. }\end{array}$ \\
\hline $\begin{array}{l}\text { The input for the } \\
\text { user ID is invalid } \\
\text { and the password } \\
\text { is valid }\end{array}$ & a-d-e & $\begin{array}{l}\text { Login fails and } \\
\text { error message is } \\
\text { displayed. }\end{array}$ & $\begin{array}{l}\text { Sign in unsuccessful } \\
\text { and error message } \\
\text { notifying user to enter } \\
\text { the correct user ID and } \\
\text { password displayed. }\end{array}$ \\
\hline
\end{tabular}

\section{Conclusion}

The UTM Games Result Enforcement and Registration System is developed according to the phases of development described in the chapter on development methodology. It started with a study of the problem statement, goals, objectives, and scope of the system. Furthermore, background studies of the relevant systems and technologies have been conducted.

After completion of the study of system requirements such as hardware and software requirements, the system design process has been carried out. Studies on technologies that can be used in problem solving are also carried out to ensure that the proposed system can be developed seamlessly and meets the system requirements. The system design process includes database design, interface design and more.

\section{References}

[1] Junaidah Binti Yusup (2012). Sistem Pangkalan Data Order Lepidoptera. Universiti Teknologi Malaysia: Tesis Sarjana Muda

[2] Mohd Azri Bin Azmi (2013). Sistem Pengurusan Pusat Sumber Fakulti Komputeran. Universiti Teknologi Malaysia: Tesis Sarjana Muda.

[3] Muhammad Faizal Bin Sidek (2009). Sistem Pesanan Makanan Mobile Meal Menggunakan Telefon Mudah Alih. Universiti Teknologi Malaysia: Tesis Sarjana Muda

[4] Sistem Pendaftaran Badan Sukan (ROSAc), [online], Available: https://rosa.kbs.gov.my/ [01 May 2013]

[5] Umirah Husna Binti Musa (2012). Sistem Pengurusan Aktiviti Ma hasiswa Universiti Teknologi Malaysia. Universiti Teknologi Malaysia: Tesis Sarjana Muda.

[6] Rani, U., Dalal, S., \& Kumar, J. (2017). Optimizing performance of fuzzy decision support system with multiple parameter dependency for cloud provider evaluation. International Journal of Engineering \& Technology, 7(1.2), 166-170.
[7] Ahmar, A. S., Rusli, \& Rahman, A. (2016). Steps in Designing Queue and Interview Process using Information System: A Case of Re-registration of New Students in Universitas Negeri Makassar. The Asian Journal of Technology Management, 9(1), 52-57. https://doi.org/10.12695/ajtm.2015.9.1.5

[8] Gunawan, A. (2015). Perancangan Sistem Informasi Wirausaha Studi Kasus: Program Mahasiswa Wirausaha Politeknik Negeri Ujung Pandang. Sainsmat, 3(1).

[9] Ahmar, A. S. (2017). SuIndiWeb: A Web-Based Platform of Sutte Indicator Predicting Movement of Stock. In Proceedings of the 2nd International Conference on Education, Science, and Technology (ICEST 2017) (Vol. 149, pp. 237-239). Paris, France: Atlantis Press. https://doi.org/10.2991/icest-17.2017.77 